\title{
INTRODUCTION
}

In 1950 a major contribution to students of English Renaissance literature appeared: Morris Palmer Tilley's A Dictionary of the Proverbs in England in the Sixteenth and Seventeenth Centuries.' It was made especially valuable for students of Shakespeare by the provision of a "Shakespeare Index" (pp. 803-808), a work-by-work, line-by-line cross-reference to almost 3,000 Shakespeare citations within the collection. One may not agree with all the citations, and one may discover that many additional passages might similarly have been recorded, but the index has been an extremely useful starting point for many editors and students of Shakespeare's language, although it has been ignored or badly misused in a surprising number of recent major editions. Two decades after Tilley, two additional proverb collections of major importance appeared: Proverbs, Sentences, and Proverbial Phrases from English Writings mainly before 1500 , edited by B. J. and $\mathrm{H}$. W. Whiting, ${ }^{2}$ and F. P. Wilson's Shakespeare-and-Tilley-minded revision of The Oxford Dictionary of English Proverbs. ${ }^{3}$ Both have been largely ignored by Shakespeare scholarship.

The present work, composed in the light of post-Tilley scholarship, including that by Whiting and Wilson, is primarily a revision and expansion of Tilley's "Shakespeare Index." To make it as useful as possible without recourse to its principal sources, the resulting index is accompanied by three separately paginated appendixes. Their purpose and relationship to the index itself are described on pp. 1-3 below.

For reasons there explained, this index should prove far less subject to misuse than its predecessor, but it needs to be employed with a comparable wariness. The next few pages, although focused upon difficulties in using Tilley and its "Shakespeare Index," suggest precautions necessary in working with this volume as well. Where possible, I use I Henry IV for illustration, partly because it is a play especially rich in proverbial elements, but mainly because it has an old Arden edition full of notes relevant to proverbs (ed. R. P. Cowl and A. E. Morgan, 1914+), a new Arden edition much better than several in its use of Tilley, though not

1. Ann Arbor: University of Michigan Press.

2. Cambridge, Mass.: The Belknap Press of Harvard University Press, 1968. Referred to as Whiting below, or as Wh when with an entry number.

Whiting. pp. $x-x$ vii, provides an illuminating discussion of his own principles of inclusion. As he implies on p. xvi, many of his entries are supported by only a single quotation and are only tentatively proverbial. This inclusiveness is one great value of his collection for any student of Elizabethan literature, but it must be used with common sense. For an entry supported only by a line from Chaucer, for example, it would be extremely perilous to assume that a recurrence in an Elizabethan author is necessarily the reflection of something proverbial. But the present index will indicate frequently how a single instance in Whiting can provide us just such assurance as we need. See, for example, on The Tur Gentlemen of l'erona 2.3.10- l2.

3. Oxford: Clarendon Press, 1970. 
ideal (ed. A. R. Humphreys, 1960), and a Variorum Supplement employing Tilley (ed. G. B. Evans, 1956). I refer to these as OA. Arden, and Variorum.

\section{Precautions ${ }^{4}$}

Tilley's Dictionary, referred to as Tilley, has been and will remain an immensely useful tool. It is the careful and thoughtful product of a man who devoted his entire scholarly career to the study of proverbs, especially Elizabethan proverbs. Nothing in the following pages intends to imply anything to the contrary. This volume is intended to replace Tilley's "Shakespeare Index" in a format usable without access to Tilley (or Wilson or Whiting); it is nothing more than a Shakespeare-oriented supplement to Tilley's Dictionary. But that Dictionary, like my own Appendix $A$ to a lesser degree, remains a tool to be used with caution. These present pages are wholly concerned with clarifying some of the reasons for that caution, especially in defining what may be called "proverbial" in Shakespeare.

Paradoxically, I shall attempt no definition of the word "proverb," and I know of no existing definition that will embrace all acknowledged examples. I would agree with James Howell, in the preface to his 1659 collection, that "the chief Ingredients that go to make a true Proverb [are] Sense, shortnesse and Salt" (although some of Howell's own examples are neither short nor salty), and I would agree that many, although far fewer than Howell implies, are "in point of Generation ... a kind of Naturall Children, and of an unknown birth ... legitimated by Prescription and long Trace of Ancestriall Time." Tilley's own solution, or rather the principal part of that solution, begins his "Foreword":

There is no agreement on what constitutes a proverb. In this collection of proverbs, proverbial phrases, and proverbial similes I have entered such material as the writers in the period from 1500 to 1700 included in their elastic conception of what was proverbial. Obviously this contemporary conception transcends the limited definition of a proverb as a saying of the folk. ${ }^{3}$ The proverb collections from these two centuries, which are the basis of our Dictionary, admitted material that seemed to their compilers to be proverbial or at least of sufficient currency to be entitled to that term.

4. This section of the Introduction is adapted from my "Shakespeare and the use of Tilley's Dictionary." an as yet unpublished essay written for $S R O$ : Shakespenrean Research Opportunities, ed. W. R. Elton. Even in references to other editions. Shakespeare lineation throughout is that of The Rin'erside Shakespeare, edited by G. Blakemore Evans, et al. (Boston: Houghton Mifflin, 1974).

5. Archer Taylor's still authoritative The Proverb (Cambridge, Mass.: Harvard University Press. 193 I) begins: "The definition of a proverb is too difficult to repay the undertaking. . . Let us be content with recognizing that a proverb is a saying current among the folk. At least so much of a definition is indisputable ..." (p. 3). 
Usually, despite some complications to be discussed later, this collectionbased principle of selections is a satisfactory one. By it, however, one can get such an entry as M475 (A man's mind often gives him warning of evil to come), supported only by a half dozen Shakespearean reflections of this familiar belief and by the $\mathbf{1 6 1 6}$ proverb collection of Thomas Draxe, from whom Tilley took the drab wording used for his entry form (i.e., heading). The collection of passages from Shakespeare is useful, perhaps well worth citing in editions, but I for one, despite Draxe, would not willingly call either his formulation or any of the Shakespearean passages "proverbial."

In addition, Tilley includes passages whose context indicates they are proverbial, whether or not they appear in any proverb collections. Once again, the principle of selection is undoubtedly sound, although it may be suspected that not every writer who called something a "proverb" did so legitimately. Thus, in Henry Porter's proverb-saturated The Tuio Angry Women of Abingdon, ${ }^{7}$ Philip Barnes speaks disparagingly of his father's servant, Nicholas Proverbes:

This formall foole your man speakes nought but proverbs,

And speake men what they can to him, hee'l answere

With some rime, rotten sentence, or olde saying.

Such spokes as the ancient of the parish use,

With neighbour tis an olde proverbe and a true,

Goose giblets are good meate, old sacke better than new.

[MSR, lines 848-853]

Line 853 is Tilley's unique example, predictably, for G93, a proverb entry that almost certainly should be deleted. For Philip's "olde proverbe" is a parody, goose giblets being proverbially worthless (cf. G364: To steal a goose and give the giblets in alms), "stinking garbage" in Nashe's terms,"

6. This index excludes extreme instances of this kind, especially when there is no corresponding entry in Wilson ( $O W$ below), but records more marginal ones. The latter are preceded by a question mark in Appendix A. Concurrence in OW, however, need not imply $F$. P. Wilson's intentional agreernent, although in some cases it may do so. Since one of Wilson's principal purposes was to provide earlier examples for entries where Tilley began misleadingly late, and since revising the ODEP did not allow him the luxury of footnotes. some Tilley-derived entries and citations obviously result from this aim. Others, one infers, must have been the result of some clerical process-for example, S150 (identical in OW705a), which consists merely of a line from the Two Gentlemen of Verona used as an entry form and supported by two passages in Lyly, both verbally dissimilar, and at least one expressing a very different idea. The present index, of course, excludes this entry (cf. Appendix (C), although Arden includes a "cf. Tilley, S150."

H305 (A good heart conquers ill fortune [overcomes all]) presents a rather frustrating and puzzling instance of such concurrence. In addition to examples verifying the existence of such a proverb. Tilley cites $2 H e n r y I V 2.4 .31 \mathrm{f}$. and $O$ thello $1.3 .206 \mathrm{f}$. I exclude both, since the first is not concerned with conquering ill fortune, and the second is not concerned with a good heart. But OW320a not only includes both but adds passages from 2 and $3 \mathrm{Henn} V I$ which seem to me even more remote.

7. Published in 1599 , but a 1590 allusion appears to date it at least a decade earlier. Anyone interested in Elizabethan proverbs and their use in the drama will wish we could be more certain.

8. Ed. McKerrow, 1, 239. 
and an old sack (not Falstaff's species of sack) proverbially a source of trouble (e.g., S8: An old sack asks much patching).

In this connection, it may be profitable to observe Shakespeare's own use of the word proverb. Most frequently the referent is a familiar sententious proverb (e.g., "A staff is quickly found to beat a dog" in 2 Henry VI 3.1.170 f.), sometimes explicitly stated, sometimes not, and with its identity occasionally open to debate.' But all usages are not of this kind. In The Comedy of Errors 3.1.51 f., a "proverb" exchange appears to consist merely of an allusion to "To set up one's staff" (S804) answered by a newly popular rejoinder, "When? can you tell?" (T88). Especially interesting is the proverb-capping battle of Henry V 3.7.113-124:

Orl. "Ill will never said well."

Con. I will cap that proverb with "There is flattery

115 in friendship."

Orl. And I will take up that with "Give the devil his due."

Con. Well plac'd. There stands your friend for the devil; have at the very eye of that proverb with " $\mathrm{A}$

120 pox of the devil."

Orl. You are the better at proverbs, by how much

"A fool's bolt is soon shot."

Con. You have shot over.

$124 \mathrm{Orl}$.' Tis not the first time you were overshot.

As noted, the sequence includes four common sententious proverbs, all in Tilley and in his index. ${ }^{10}$ But the context implies, in addition, that there must be something proverbial about "A pox of the devil" ( $119 \mathrm{f}$.), and very possibly about "shot over" and "overshot." Let us begin with the last. Compare the 1616 Draxe mentioned on p. xiii (one of Tilley's principal sources, but one he employed with some puzzling inclusions and omissions), s.v. Wisdome, no. 2438: "A wise man may sometimes overshoot himselfe." In the present index, keyed to Tilley, this becomes M427.1; in Appendix A, it is supported by earlier instances. It seems clear that line 124 alludes to this conventional sententious proverb.

The same proverb might seem to account for line 123, although it would be awkward for two speakers in a contest to use the same proverb. They do not, even though the two are closely related, and the nonsententious one for 123 must precede the other. Because tongue-tied, for example, occurs in John Heywood's famous dialogue of proverbs, and hence "To be tongue-tied" in Tilley, OW, and Whiting, this present index

9. See on A Midsummer Night's Dream 3.2.463, The Merry Wives of Windsor 3.5.152, Romeo and Juliet 1.4.37 f., and Coriolanus 1.1.207.

10. I am somewhat misleading. Tilley, followed by OW243b, enters $114 \mathrm{f}$. under F4I, inserting a parenthetical "(Hattery)" into the common "There is falsehood in friendship," although giving no other example with flattery. My index instead excludes F4 I and cites two alternate proverbs that parallel the idea but not the precise wording. 
nervously but dutifully records every instance of the word in Shakespeare. $H e n n y$ makes clear that Shakespeare would have expected an equally simple entry for "To overshoot oneself (be overshot)." 091.1 in Appen$\operatorname{dix} A$ cites instances from cl530, including 1546 Heywood and three other passages in Shakespeare.

As for "A pox of the devil," which appears in context more necessarily proverbial than the two passages just examined (if that is indeed what is "proverbial" in lines 118-120), I have nothing helpful to suggest. $O E D$ s.v. Pox sb. 3 gives various examples of $A$ pox on or of (I should probably have included the expression in my Appendix B), but only this with desil. Nor have I noted the expression elsewhere. We can scarcely assume, despite the context, that there should be an entry for "A pox of the devil," although proverb is used broadly enough in Shakespeare to include such a phrase. Nor can we assume, conversely, that every context-determined entry in Tilley reflects what Shakespeare had in mind. In The Tuo Gentlemen of Veroma 3.1.304 f., for example, despite B450/OW85a (Blessing of your heart, you brew good ale), I suspect the "proverb" may be no more than the phrase "Blessing of your heart."

Nevertheless, Tilley's first two criteria for determining entries are generally beyond cavil. A third principle of inclusion, although it contributes greatly to Tilley's usefulness, is more questionable in a dictionary of proverbs:

In addition to recording admitted proverbs, I have, where I found recurring independent instances of the same thought in printed works of the period, included such sayings as well, preferring to err on the side of inclusiveness rather than on the side of exclusiveness. I have entered pithy expressions of old truths or of accepted facts, the observations of generations, warnings, admonitions, guides to conduct, accumulated wisdom that has stood the test of time.

Thus, even when supported with a proverb collection, a good deal of Tilley's informative data can be described as "proverbial" only with reservation, if at all. This is probably true of G449/OW338b (Grief pent up will break the heart), a recurrent idea never given any characteristic verbal formulation such as one tends to expect of full-fledged proverbs; it may well be true both for the entry form and for most of Tilley's examples under Biblically based C23/OW230b (Everyone must walk [labor] in his own calling [vocation]), although a few examples suggest that Falstaff's wording in 1.2.104 $\mathrm{f}$. intentionally perverts a formulation that could be called proverbial (neither Variorum nor Arden cites Tilley);" it is cer-

11. Some editors are inclined to reject the claim for "proverbial" on passages whose ultimate origins are Biblical. For such an entry as L250/OW46 Ib (Life is a shutde), which consists merely of a quotation from Job and one from The Merry Wives of Windsor, they would undoubtedly be correct. But Falstaff abundantly illustrates that many Biblical entries are legitimately "proverbial." When he and Prince Hal play upon "wisdom cries out in the streets, and no man regards it" (1.2.81-89), nothing "proverbial" from an Elizabethan point of view is involved, even though the origin is in Proverbs 1.24. But when Falstaff Euphuizes 
tainly true for N307, Tilley's first entry for $I \mathrm{Henry} I V$. This last I exclude from my index, instead recording it in Appendix $\mathrm{C}$ with the explanation "Not a proverb." Here Arden's note, warning that the idea reflected in 1.1.106 f. is only "quasi-proverbial," is considerably more satisfactory than Variorum's noncommittal "TILLEY" (1950) N307: Nothing is well said or done in a passion (in anger)." One could give further instances by the score (cf. Appendix $\mathrm{C}$ )-for example, the entry on vengeance belonging only to God (V24), ${ }^{12}$ or on the dangers of fresh air for a diseased or wounded man (A93)-especially if one included all instances of folklore lacking proverbial formulations.

A Tilley-like Dictionary devoted to folklore and superstition would be a useful tool. Such an entry as the following could remove the puzzlement of $O A$ and could replace the silence of Arden:

\section{D623.1 DROWSINESS is ominous}

c1591 (1592) Arden of Fenersham v. 17: This drowsiness in me bodes little good. c1592 (1594) Marlowe Eduard // 4.6.44 f.: Drowsiness Betides no good. 1620 Melton Astroluguster G3v: If a man be drowsie, it is a signe of ill lucke.

Shakespeare: Tit. 2.3.195-197 (just before catastrophe for both) [My sight is very dull, what e'er it bodes. / And mine, I promise you; were it not for shame, Well could I leave our sport to sleep a while.]

No such entry appears in Tilley, but analogous entries do. Probably not one out of every dozen Elizabethan superstitions receives an entry, and anyone interested in Shakespeare's use of proverbs should realize that, with rare exceptions, those that do appear are no more "proverbial" than those that do not. One of Tilley's two Shakespeare citations under T259/ OW818b (To stumble at the threshold) ${ }^{13}$ illustrates the point. It alludes to

on the defiling effect of touching pitch (2.4.410-414), or defends his "frailty" (3.3.167 f.), he is playing with what was incontestably proverbial (P358, F363; Arden acknowledges the latter). One further instance is somewhat interesting. For Falstaff's "If then the tree may be known by the fruit, as the fruit by the tree" (2.4.428 f.), Arden cites Scripture and Lyly (as it does for 2.4.410-414 above); both undeniably contain the first half of Falstaff's line. Both halves are proverbial, however, as T497 makes evident; Whiting gives each a separate ent ry ( $T 472,465$, the latter varied).

12. A very inadequate entry, incidentally, both in its Biblical and its Elizabethan citations. OW673a revises to a legitimate proverb (Revenge is a morsel for God), but retains Tilley's citation of Rirhard II 1.2.6-8, which has no hint of this blasphemy. John of Gaunt was no speaker of what were called "Satan's proverbs." See on \$300.

13. This is a proverb only when used figuratively; cf. fn. 22 . Somewhat inconsistently, 1 retain R33/OW665a (with a question mark in Appendix A) on the ominous raven, but exclude B99/OW3 Ib (The basilisk's eye is fatal) and C495 (The cockatrice slays by sight only). These I replace with more legitimate entries, proverbial similes: "To kill like a basilisk" (B99.1) and "To kill like a cockatrice" (C496.2).

Although all the following seem to me more folklore than proverb (each accordingly gets a question mark in Appendix A), the index for A Midsummer Night's Dream retains $\$ 66 / O W 696$ b/Wh S26 (On Saint Valentine's day all the birds in couples do join). S490/OW817a/Wh S353 (The three sisters ["the Sisters Three" by proverb-loving Launce in The Merchant of Venice 2.2.63 suggests my question mark may be a mistake]), even M240/OW504a/Wh M138 (The man in the moon), but with a protesting footnote on the latter. Supported by Whiting, thr. : rlex courageously excludes $R / 47 / 0$ W68 la (Robin Goodfellow). 
a wholly different superstition, but one that might with equal justice be called "proverbial": "Three times to-day my foot-cloth horse did stumble" (Richard III 3.4.84). On dying Hotspur's "O, I could prophesy" (5.4.83), Arden provides what seems to me an appropriate note, one that makes Tilley's information available without any implication of its being proverbial: "cf. Tilley, M514—'Dying men speak true (prophesy)' $;{ }^{14}$ an allusion to the belief that a dying man can foretell the future ..."; here the Variorum is sensibly silent, since Tilley's nonproverb adds nothing to earlier Variorum notes.

So much for the need for caution as it relates to Tilley's three principles of inclusion. Another source of difficulty, as with any comparable dictionary of proverbs, is the entry form. Here the resulting danger, as obvious as it is inescapable, is often ignored. A group of passages gathered together under an entry form that sounds proverbial may or may not support the legitimacy of the entry. H292 (To drink health is to drink sickness) sounds very like a proverb; instead, it is simply a slight misquotation from Dekker (who has healths), and the examples supporting it are merely variously worded warnings on the physical and financial consequences of drinking excessive toasts. The Arden Timon of Athen.s, misled by the entry form, in turn misleads its users by describing $1.2 .56 \mathrm{f}$. as "A variation on the proverb"; there is no evidence that any such proverb ever existed. The most easily misused entries of this kind, of course, are those where the entry form is verbatim, or nearly verbatim, Shakespeare (a fact noted where pertinent in my Appendix A). For example, D354/OW 189b (Discretion is the better part of valor) takes its entry form from a slight reordering of Falstaff's famous rationalization. That discretion is an essential component of true valor is an ancient idea, as $\mathrm{OW}$ makes evident, and its formulation by Falstaff has long been proverbial, with echoes beginning as far back as Fletcher; but our present evidence does not warrant Arden's simple description of 5.4.119 f.: "Proverbial; Tilley, D354."15

14. M514 muddles together two quite different elements-the superstition specified by Arden (which I exclude) and the more rational conviction, perhaps proverbial, that dying men speak true. Several of Tilley's entries for thoroughly legitimate proverbs similarly, but more seriously, need division: for example, E I 16, which fails to distinguish between the end as triumph and as judge (a distinction clear in $O W$ and Whiting); F585, which equates our desire for the forbidden with our desire for the self-destructive (OW excludes the latter); and F604, which combines the abhorrent blindness of Fortune with the admirable blindness requisite for Justice (OW mistakenly has no entry for the latter). Less important are the instances where entries might well be combined without loss (almost always they are crossreferenced to one another). Thus S574, under which Tilley cites Hotspur's "O he is as tedious / As a tired horse, a railing wife, / Worse than a smoky house" (3.1.157-159), is merely a minor variant of $\mathrm{H} 781$. While Arden cites both. Variorum cities neither, presumably satisfied by the single quotation from Chaucer provided ever since Steevens. This is misleading.

15. Akin to the misleading $\mathrm{H} 292$ are L568 (merely The Merchant of Venice 2.6.4 and a wholly nonverbal analogue in The Tu'o Cientlemen of Veroma; the Arden Tu'o Cimtlemen, nevertheless, says "cf. Tilley, L568"), and C918 (Troilu and (irewidn 1.3.389 with a paren- 
If an entry form can mislead us into calling something proverbial that is not, it can similarly encourage our missing something actually proverbial. Take the 1530 citation under C706 (Oft counting makes good friends): "The commune proverbe is that ofte rekenynge holdeth longe felawshyp." For me, at least, this clarifies the jest in what has otherwise seemed a pointless line: Falstaff's "Well, thou hast call'd her to a reckoning many a time and oft" (1.2.49 f.). The entry form obscures it completely. Troublesome in a slightly different way is D148/OW 174a (Death pays all debts), undeniably a proverb of the period, although our earliest known unmistakable example is Tilley's third citation from Shakespeare: The Tempest 3.2.131. The wording of the earliest citation, however-Prince Hal's "the end of life cancels all bands" (3.2.157)-so closely resembles the "common saying" cited for 1603 and the following citation of 1609 that the three should perhaps have been given a separate entry. ${ }^{16}$ Arden is misleading: "The sentiment is proverbial: 'Death pays all debts' (Tilley, Dl48)"; Variorum is silent. Just such an additional entry OW $186 \mathrm{~b}$ provides for Tilley's second Shakespeare citation under D148: 2 Henry IV 3.2.238. Citing 1578 Thomas White, but not Shakespeare, it nevertheless informs us that Feeble's "He that dies this year is quit for the next" had been disapproved a generation earlier as a "Heathen proverb ... too common among Christians" (D326. 1 in this index and Appendix A). Only the chance survival of a single sermon assures us that proverb-mouthing Feeble was not, on one occasion, surprisingly original. Rather than the mere entry form for D148, apparently, there were at least two-perhaps three-closely related but verbally distinct proverbs, with Shakespeare providing an example of each of them. These illustrations are enough, I trust, to show the danger of ever assuming that an entry form adequately represents the content of the entry as a whole. ${ }^{17}$ It would be easy to provide more, especially since a

thetical ["bite"] to allow two late instances of an actual proverb, a proverb differently worded and with a wholly different sense). Both are relegated to Appendix $C$.

A bit more defensible, and hence included with a question mark, is M1050. The entry form is The Mern Wires of Windsor 2.2.168 f., with do omitted. Arden calls it "a popular maxim," but the four supporting entries have verbally nothing in common beyond the word momer, and they share only a very widespread and ancient idea.

16. Because the 1609 entry may be a mere echo, I decided against making a separate entry.

17. Some proverbs admit so many variations that they defy any adequate entry form. An extreme example is B607: "His old brass (cloak) will buy you a new pan (kirte)," under which, along with many other variations, one finds "An old cloak makes a new jerkin" (The Mern Witen of Wimdsor 1.3.17) and "your old smock brings forth a new petticoat" (Antony and Cleoputru 1.2.168 $\mathrm{f}$. The present index amends the entry form to "His old brass (etc.) will buy (make) you a new pan (etc.)," which scarcely helps much. Thanks to Tilley's "Shakespeare Index," it has long been easy to correlate these two passages with B607. Had he missed either of them, things would be more difficult. For Tilley's terminal "Index of Significant Words," unlike that in Whiting. limits itself to words in the entry forms. The Wire' passage could eventually be found among the thirty entries under Clonk, and the Antomy passage, theoretically, after looking in vain under. Smork and Pettirest, amid the hundred or so entries under Oll (except that $\mathrm{B6007}$ is not listed under Old, although the index is an exceptionally full and accurate one). As for Hal's "The end of life cancels all bands." discussed above, one could find it in Tilley's index only by guessing that "the end of life" might, in the entry form, prove to be "death." 
favorite source for Tilley's entry forms is the proverb collections of the late 17th and early 18th centuries, those of John Ray and Thomas Fuller, M.D., most of all. Early citations under these forms, if any, may be of most interest for Shakespeare when least like the form.

Mention of Ray and Fuller can introduce the problem of dates, a problem ignored or slighted by many Arden editors (grossly by a few). Although Hilda Hulme is partly right in assuming "a proverb will take root in the spoken language before it finds a place in the printed collections," ${ }^{\prime 8}$ the fact that Tilley records a passage from a late collection need not mean it was proverbial in Shakespeare's day; frequently it may not mean that the passage was proverbial ever. Near the conclusion of Howell's 1659 "English Proverbs," for example, are two passages for which Tilley's only earlier examples are from Bacon's 1612 Essays (M547, W379). Both then reappear, just as we would expect, in 1670 Ray and in 1732 Fuller. Should we then infer that they were proverbs when Bacon wrote them? Or even by the time of 1732 Fuller? I doubt it, and I am glad that OW excludes both. ${ }^{19}$ Equally dubious are many entries where the proverbial quality of a passage from Lyly is supported mainly by 1732 Fuller (in at least twenty-five instances only by him), for it would be easy to prove that Fuller (or some contributor to his collection) worked directly from copies of Euphues and Euphues and his England, sometimes even for common proverbs. ${ }^{20}$ Fuller's title page, we must realize, does not promise that all "witty sayings" in the collection can be called "proverbs." Thus, when a passage in Shakespeare is only analogous to one in Lyly, we need more than Fuller before calling the Shakespeare "a variation on [or 'an expansion of'] the proverb." And I would be at least as hesitant so to describe (as does the Arden Comedy of Errors 2.1.34-37) a passage with nothing outside Shakespeare except Fuller. (In this instance, I should concede, analogues preceding Shakespeare can be found under M182.)

For $I$ Henry IV 3.1.58,61, Variorum omits T566 (Speak the truth and shame the devil), presumably considering the earlier Variorum's reference to 1678 Ray quite enough. Tilley's entry reassures us that the proverb was indeed common even before Shakespeare was born. But for Falstaff's "Hang thyself in thine own ... garters" (2.2.43 f.)-where, pre-

18. Explorations in Shakespeare i Language (London: Longman, 1962), p. 49.

19. In John Webster's Borrouing (Berkeley: University of California Press, 1960), p. 285. concerning a passage in "A Divellish Usurer," I glibly wrote: "James Howell, probably with no awareness of the present passage, offers an almost verbatim version in his 1659 collection of proverbs. ... Tilley, U28, begins with Howell." On the matter of awareness I was demonstrably wrong. The same page (with both Bacon passages nearby) includes "A Drunkard is doubly divorced from himself, for when he is got sober, he is scarce his own man, and being in drink, he cometh short by many degrees." This makes better sense in Burleigh's Certaine Prpcepts (c 1598 [16 17]), sig. A6 f., for it there concerns a drunken seriant. This particular section of Howell, clearly, has plenty of nonproverbial borrowings in it.

20. For example, Fuller's unusual version of the very common $\mathrm{H} 160$ (You shall as soon catch a hare with a (abor) is verbatim from an uncited passage in Euphues and his England (ed. Bond, II. 99). 
sumably for the same reason, Variorum does not cite G42-Tilley has no examples prior to Shakespeare, and only Harington's 1591 Ariosto has since been discovered (OW349b).

It is similarly perilous to assume something is proverbial where the only cited examples outside Shakespeare may merely be echoes. Conceivably this is true of Hal's "the devil rides upon a fiddle-stick" (2.4.487 f.), which Arden unquestioningly annotates with "Proverbial; Tilley D263," although the three other known instances are in later plays by Fletcher and Brome-Heywood. (Characteristically, and, in this instance, probably correctly, $O A$ is similarly positive, pre-Tilley, on the basis of the same evidence.)

Closely related to the problem of "echoes," if not identical with it, are difficulties caused by the extensive borrowing from one another practiced in widely varying degrees by virtually every author of Shakespeare's day. Until proved mistaken (which may well happen), I shall continue to think Sidney's Astrophil the originator of "I am no pickpurse of another's wit." But I have seen the same claim, verbatim in its essentials, in translator Sir John Harington (1591), astrology-defender Sir Christopher Heydon (1603), epigrammatist Henry Parrot (1608), preacher George Benson (1609), and poet William Drummond (1615)-more evidence of currency than Tilley provides for at least half its entries. The expression should probably be added to Tilley, but we have at present no reason to think it was proverbial when Sidney used it, or even when Harington did so.

In such an age of pickpurses it is frequently difficult, or impossible, to identify what Tilley called "independent instances of the same thought" (see above, p. xv); a good many Tilley entries, certainly, provide more evidence of borrowing than of anything one can call genuinely proverbial. Let me illustrate the problem, however, with four passages not cited by Tilley:

1579 S. Gosson, The Srhoole of Abuse, sig. A2: "The Syrens songe is the Saylers wracke: the Fowlers whistle, the birdes death: the wholesome baite, the fishes bane: The Harpies have Virgins faces, \& vulturs Talents [cf. H176.1]: Hyon speakes like a friend, \& devours like a Foe: The calmest Seas hide dangerous rockes: the Woolfe iettes in weathers felles [cf. 1575 Gascoigne under W614 (A wolf in a lamb's skin): Wolves do walke in wethers felles].

1595 R. Turner, The Garland of a greene Witte, sig. B4": "the Siren sweetly sings $y^{e}$ Saylers wracke"; sig. C1: "the Scarabe flyes over many a sweet flower, and lights on a Cowshard [B22 1; Gosson, sig. A 1 ${ }^{\mathrm{v}}$ ] . . the Sirens song is the Saylers wracke, the Fowlers whistle the birds death, the wholesome bayte the Fishes bane, the Harpies have virgines faces, the vultures talents. Hienna speakes like a friend, and devours like a foe, the calmest seas hides dangerous rocks, the Woolfe iets in Weathers fells." 
1601 A. Dent, The Plaine Mans Path-Way to Heaten, sig. M6: "These men are like . . a daungerous rocke hid under a calme sea. Or as the Heathen say: Like the Syrmus song, which is the Saylers wracke. Like the Fowlers whistle, which is the birds death. Like the hid baite, which is the fishes bane. Like the Harpies, which

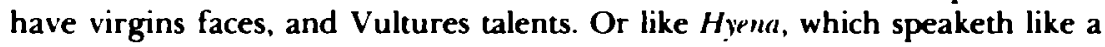
friend, and devoureth like a foe.

1609 D. Tuvil, Exwryes, Morall and Theologicall, sig. G3": "Saith the Italian Proverb. Every mans looke is not the mappe of his meaning. The Syrens song is the sailors wrack; the Fowlers whistle the birds death; and the wholesome baite the fishes bane."

The Gosson passage (like several others in this little work) could easily introduce several additional entries for Tilley (cf. H176.1), and the degree of their interrelationship would be hidden by their being scattered throughout the Dictionary. What is true for these potential entries is equally true for many actual entries, as I have suggested by the bracketed notes above. But some of these potential entries, despite the particular evidence of borrowing indicated above, may have been, or have become, legitimate proverbs.

If Tilley's inclusiveness in his almost 12,000 "proverb" entries is one source of difficulty, so, too, is his inclusiveness in Shakespeare citations. Although the Foreword never explicitly says so, many of these must surely have been intended as suggestions for consideration rather than as declarations of supposed fact (just as are many citations with a question mark in the present index). Despite its title, Tilley is by no means a dictionary in the sense that the $O E D$ is one, and its compiler must have endlessly regretted a format that precluded his explaining the rationale underlying some of his inclusions. It is no surprise to see that many such suggestions are rejected by editors (never, one hopes, without due consideration of Tilley's possible reason for citing). ${ }^{21}$ Of the nine Shakespeare passages under F3 (Fair face, foul heart), for example, only two seem to me similar enough verbally to be worth mention (the clearest is Lady Macbeth's "False face must hide what the false heart doth know"); the others might just as easily have been included under F29 (Fair without but foul within), or merely omitted, as sharing no more than an extremely common idea. The present index excludes them (although my F3 has six Shakespeare citations). It similarly excludes citations that are literal applications of some-

21. I doubt that either Variorum or Arden so considered what seems to me the clear relevance to I Henry IV 4.4.34 f. of W912 (It is good to fear the worst), an unmistakable proverb reflected several times in Shakespeare, as Tilley and the present index indicate. Had Arden done so, it would not have preferred Capell's semicolon after fear to Pope's deletion of a comma in the original text. Arden reads: "yet needful 'tis to fear; / And to prevent the worst, Sir Michael, speed." The retention of the original comma in the Riverside text is somewhat less objectionable. Probably both should have heavier punctuation after u'orst. 
thing proverbial only when figurative. There is nothing proverbial about literally kissing the ground, or dancing barefoot, or blowing one's nails, or putting one's finger to one's lips. ${ }^{22}$ Even so, given the implied intention of citing every relevant passage, Tilley entries are sometimes surprisingly incomplete. One aim of the present index and of Appendix A is to compensate not only for this shortcoming, but for that discussed next.

What is true for individual entries is true for individual works; for some, the number of Shakespeare citations seems relatively excessive (although, in every instance, my own index adds at least as many Tilley entries as it excludes) ${ }^{23}$ for some, it seems much too spare. The late J. C. Maxwell, an expert on Elizabethan proverbs, tacitly rejected 27 of Tilley's 62 entries for the Arden Titus Andronicus, at least 8 because he must have considered them too common or too trivial to mention (this index excludes 10); Clifford Leech's The Tu' Gentlemen of Verona, in contrast, cites so many of Tilley's 75 entries that I suspect the two omissions (P326, U22) may have been accidental (I exclude 7, but neither of the pair just named). As for 1 Henry IV, I would expect an ideal edition to cite at least 61 of Tilley's 111 citations, frequently on the basis of additional evidence not available to Arden or Variorum. Arden cites only 41, Variorum only 38, partly because rarely willing to mention Tilley for passages called proverbial by previous editors, however slight their evidence. The present index excludes 19, but it adds enough from Tilley and elsewhere to end up with 187. Admittedly, many of these.I would totally ignore were I an Arden or Variorum editor.

In this connection, one further word can be said about such fully annotated editions as the Arden and Variorum. Some of the OAs spend a depressing proportion of their available space citing parallels from Shakespeare's predecessors, contemporaries, and successors. Tilley, or the present index, often allows extensive space saving. For Hotspur's repeated "tell truth, and shame the devil" (3.1.58, 61), Arden's "Proverbial; Tilley, T566) adequately replaces eleven lines in OA and assures the reader, as OA's examples do not, that the proverb was indeed current prior to Shakespeare. ${ }^{24}$ Arden itself could have replaced most of 36 lines on "Saint Nicholas' clerks" (2.1.61 f.) with a mere "cf. Tilley, S54." But unless the editor employs such condensation with care, he may mislead

22. I have excluded, for example, literal references to thumb-biting in Romeo and Juliet 1.1.42-51 (T273 OW62a), to looking to one's water in $2 \mathrm{Henry} I V 1.2 .1 \mathrm{f}$., (W109/OW483b), to stumbling at the threshold (T259 $\mathrm{WW} 818 \mathrm{~b}$; see $\mathrm{p}$. xvi above), and to means of recognizing the devil in Othello 5.2.286 (D252/OW 182a). 161 I Cotgrave s.v. Diable (on the last named) well illustrates the distinction: "On cognoit le diable a ses gristes: Pro. The divell is knowme by his clawes; a covetous heart discerned by catching hands." Othello's "I look down at his feet; but that's a fable" is literal.

23. See "Principles of Inclusion" below and p. 3 f.

24. In composing Appendix $A$, I have drawn frequently upon $O A$ annotations that have wholly or partly disappeared in Arden. Admittedly, some $O A$ suggestions did not merit survival. See, for example, on 1 Henry IV 2.1.43. 
the reader. Thus, for the first half of Falstaff's "happy man be his dole, say I-every man to his business" (2.2.76 f.), Arden's unsupported "Proverbial" needs only "Tilley, M 158" to replace adequately twenty-seven lines in OA. But for the second half, on which OA is silent, Arden's "Proverbial: 'Every man as his business lies' (Tilley, M 104)" is overly simple. M 104 consists of 1678 Ray, which provides the entry form, Falstaff's words, and a repetition of Falstaff's words in 1682 Aphra Behn, very possibly an echo.

One final problem should be noted, with which the present index attempts to deal. Tilley sometimes cites Shakespeare for one relevant entry when another may be of considerably greater interest. Such seems to me to have occurred with the following dialogue:

Prince. Did I ever call for thee to pay thy part?

Falstaff. No, I'll give thee thy due, thou hast paid all there.

[1.2.52 f.]

Arden (like OA) has nothing. Tilley suggests D634, an approximation of Romans 13.7: "Render therefore to all their dues." Variorum, even though Tilley had not suggested it, supplements with the more demonstrably common D273 (Give the devil his due), explicitly used sixty-five lines later. This suggestion seems to me correct, but bettered by the addition of still another: the almost equally common D288 (Let the devil pay the maltman). As in line $49 \mathrm{f}$. (on which see $p$. xviii above), we recognize the jest or barb only if we know the pertinent proverbs.

\section{Problems of Completeness}

Appendix A allows brevity in this portion of the Introduction on the need for a supplement to Tilley's entries, and even to those added by $O W$. Roughly one-fourth of the entries in Appendix A (all decimaled) do not appear in Tilley, and, of these, a great many do not appear in OW either. This is not a criticism but merely a statement of fact.

Any dictionary of proverbs, or index to Shakespeare's use of proverbial language, is bound to be incomplete. This is partly because of blind spots in the compiler and partly because of pertinent evidence not yet seen. Were I to continue working on the present index a few more yearschecking in detail the many 17 th-century proverb collections I have not even looked at, or reading every extant play to 1700 -no doubt this index would grow longer by at least a hundred entries, possibly by far more than that. A revised Dictionary, not restricted to "Shakespearean" entries, would certainly expand by hundreds.

It should be no surprise that Wilson and Whiting found pertinent proverbs unknown to Tilley, or that I have found some unknown to 
Wilson and Whiting. It was a surprise to me, I confess, to discover how much in Lyly and Pettie (most of it irrelevant to Shakespeare) escaped Tilley's Dictionary, for Tilley's first major publication was Elizabethan Proverb Lore in Lyly's Euphues and in Pettie's Petite Pallace; ${ }^{23}$ it was also surprising to discover how much Nashe was not in OW, since a supplement to McKerrow's Nashe was one of Wilson's best-known contributions to scholarship. It was again a surprise to discover how frequently pertinent passages in Heywood's Dialogue, ${ }^{26}$ or in such compilations as I did examine with care (1530 Palsgrave, c1580 Conybeare, 1616 Draxe, 1639 Clarke), appeared in neither Tilley nor OW. Others may be comparably surprised by gaps in the present volume.

Some degree of incompleteness, however, is irremediable. As already illustrated by Freeble's "He that dies this year is quit for the next" (p.xviii), sometimes we learn only by a stroke of luck that something in Shakespeare was unmistakably proverbial at the time he used it. With some of Feeble's cousins, we can feel almost as certain even without such evidence. No one imagines that Dogberry could have originated "And two men ride of a horse one must ride behind," nor would we do so if a single c1640 recurrence had not allowed the proverb entry in Tilley (T638). For largely the same reason, we may be willing to accept Arden's "a popular tag (Tilley, T5 18)" for the First Carrier's "I know a trick worth two of that" (I Henry IV 2.1.36 f.), although Tilley's other examples are all from plays more than a decade later (which OW839a supplements only with instances from the 18th and 19th centuries). Here we may feel little need for the reassurance of Wh G24, with its single example from a 1400 : "I con a game worthe thei twoo," although only the Whiting entry allows Appendix A to use no question mark. Within the same First Carrier context, I would be willing to accept the carrier's "as good deed as drink" (2.1.29) as "proverbial" (OA), or at least as "a popular tag" (Arden) - perhaps modified by an "apparently" or "almost surely." The expression is not in Tilley, and there are no known instances outside Shakespeare until Sir Wilfull Witwood in Congreve. It is difficult otherwise to account for Falstaff's sharing the whole of an expression with the First Carrier, and the bulk of it with Sir Andrew Aguecheek. Hence Appendix A's unquestioning entry: D183.1.

The First Carrier can introduce a different species of incompleteness in Tilley, almost certainly intentional, and usually thoroughly defensible. In the following passage (2.1.22-31), all the italicized expressions other than

25. New York: Macmillan, 1926.

26. Predictably, given the popularity of Shakespeare and the care of scholars, little has escaped attention beyond a few phrases or influences upon Shakespeare's diction. But they can be called "proverbial" as legitimately as those treated in fn. 28 below. See on F672.I. T456.1, and in Appendix B BB4, PP13, SS19, SS26, WW34. More interesting are entries involving the question of what, in Heywood's verse dialogue, he intended to be recognized as proverbial (e.g., O91.1, discussed above, p. xv). See on A211.1, B450, B686.1, P73, S97, W257. 
the one just discussed were common colloquialisms, obviously a major aspect of Shakespeare's characterization; but Tilley cites nothing below in his "Shakespeare Index," nor does the present index cite any Tilley entries. What it does cite, and what it ignores, is indicated below:

1. Car. What, ostler! come au'ay and be hang'd [H130.1, with fn]! come au'er).

2. Car. I have a gammon of bacon and two razes of ginger, to be deliver'd as far as Charing-cross.

1 Car. God's body, the turkeys in my pannier are quite starv'd. What, ostler! A plague on thee [App. B]! hast thou never an eve in thy head [cf. E248. 1, with fn]? Canst not hear? And twere not as good deed as drink [D 183.1] to break the pate on thee, I am a zery villain [J49.1]. Come, and be hang'd [H130.1]!

Why Tilley (and OW) excluded "as good deed as drink" I am not sure, perhaps because neither was aware of any instance outside Shakespeare (but both have entries consisting exclusively of Shakespeare). The rest Tilley undoubtedly excluded on the ground that oaths, imprecations, and the like should be ignored (although L374 [As sure as you live-one of Kate's three reported oaths in 3.1.249 f.] and G266 [God's blessing on your heart for it] are minor departures from this principle). Fifteen years before the publication of his Dictionary, Tilley had noted that "Come away and be hang'd" appears in Merbury's proverb-laden Marriage Betueen Wit and Wisdom $;^{27}$ nevertheless, he denied it an entry. One cannot call Tilley's decision on oaths mistaken, but given his extreme inclusiveness in other respects, ${ }^{28}$ one can wish he had been a little less exclusive in this one. An awareness of such colloquial elements, whether or not they can be called "proverbial," is very useful when examining dialogue in Shakespeare. My own not very systematic solution is suggested by the brackets above, and by

27. Shakespeare Aworiation Bulletin, 10 (1935), 91. But, as noted in Appendix A, a version appears in at least one of the 17th-century collections used by Tilley.

Wilson somewhat muddies Tilley's distinction by adding two more oaths of Shakespearean interest: "God save the mark" (cf. G179.1) and "By this fire, that's God's angel" (G264.1). $\mathrm{He}$ also adds another variant on "Come away and be hang'd (OW245a: Farewell and be hanged), almost certainly because he objected to Tilley's using 1670 Ray for F733's entry form (Farewell and be hanged, friends must part), thereby submerging a legitimate proverb, for which Wilson had several earlier examples (OW290b: Friends must part). As a consequence, "Farewell and be hanged" appears as a proverb in OW, although "Come (away) and be hanged" does not. H130. I combines the two.

28. What follows serves to supplement earlier references to Tilley's inclusiveness. It concerns entries that basically involve merely a single word (in which case I have simply listed that word, the key to Tilley's entry) or an extremely simple phrase. All but one appear in OW as well as Tilley. I retain them in Appendix A with a parenthetical "cf. Appendix B": carpet knight, catercousins, cockney, cold comfort, come what will, to be dog at something, eyesore (in Wh, not $O W$ ), a fig for him (it), that's flat, right hand, hob nob, at an inch, to play the jack (but not knave, fool, etc.) with one, Jack-a-lent, true lover's-knot, merry Greek. Monmouth caps, mumbudget, laced mutton, nightwork, in a pickle, pissing-while, in print (under Man), to pocket up (under Injury), in a quandary, to pick a quarrel, saving your reverence, smoke. tag and rag, trencherman, in a trice, utterly undone, vease, with a witness, go whistle. 
sporadic explanatory footnotes in Appendix A. Most oaths I exclude, but $I$ retain those in Tilley and $O W$ and $I$ add a few, usually for reasons explained in footnotes. Some colloquialisms I ignore as simply too common to note, some $I$ relegate to Appendix B, and some I enter in Appendix $A$. Whenever uncomfortably aware of my inconsistencies, $I$ have comforted myself with a proverb created by Emerson.

\section{Principles of Inclusion}

In the preceding sections and their footnotes I have said a good deal about principles of inclusion and exclusion for the following index. A bit more needs to be said.

To begin with, it is not the business of such an index as this to be selective. The present index is intended to be as complete a crossreference as possible to relevant entries in Tilley, to OW and Whiting where these usefully supplement Tilley, and to any additional evidence of which I am aware. Undoubtedly there are some obvious omissions, especially in recording the most common colloquialisms and proverbial similes (with some plays-Hamlet, for example-the ratio between significant citations and trivia is already embarrassing). But failure to cite sententious proverbs should be rare. If a proverb-sounding piece of sententiousness by Friar Laurence, or Gaunt, or Polonius, or the Duke of Venice (none of whom uses proverbs to any degree) fails to be cited, it fails because I know nothing worth citing. With Polonius, certainly, I have erred on the side of inclusiveness. ${ }^{29}$

I have said "as complete as possible," and in a sense that is true. But, as explained in footnote 2 on Sonnets, nearly one-fourth of my citations in that index are included only because their relevance is defended in the commentary of Stephen Booth's invaluable edition. ${ }^{30} \mathrm{I}$ rely on that commentary as my defense for these inclusions. On the other hand, to be equally full on Shakespeare's other works would require an endless commentary of my own. For most users this would prove more a distraction than a help.

A few illustrations of inclusions and exclusions may be helpful, although some may imply no high degree of consistency in my decisions. Take Lysander's rejection of Hermia in A Midsummer Night's Dream. Because of a possible, barely possible, link between "you Ethiop" and "thou

29. See on Hamlet 1.3.69. Although I have excluded six of Tilley's entries for 1.3.20-80 (the dialogue ending with Polonius's counsel to Laertes), I have added three, and my index thus includes fourteen (i.e., almost 8 percent of the entire Hamlet index for far less than 2 percent of the play). But a glance at Appendix $A$ shows that very little in these lines can legitimately be called proverbial.

30. New Haven: Yale University Press, 1977. 
cat" (3.2.257-260), the index cites without comment two expressions based on a single Biblical passage. Conversely, the index ignores "you acorn" (line 330), although A22 (From acorns come oaks) indicates their proverbial smallness, and two closely related proverbs in OW32 (To esteem acorns better than corn; Acorns were good till bread was found) employ arom. contemptuously. As for the "you bead" that precedes "acorn," I wish there were textual warrant, even from a Pope or Theobald, allowing the index to cite B 118 (Not worth a bean; cf. Wh B82-92, all antibean). Shakespeare nowhere else uses bend with comparable implications.

Earlier in the same scene (lines 138-143) Demetrius adores Helena with a series of what are essentially very conventional images:

To what, my love, shall I compare thine eyne?

Crystal is muddy. $O$, how ripe in show

Thy lips, those kissing cherries, tempting grow!

That pure congealed white, high Taurus snow

Fann'd with the eastern wind, turns to a crow

When thou hold'st up thy hand.

For such a passage it may seem ridiculous to cite three "proverbial" similes, a proverbial phrase," and then Appendix B for "cherry lips." But completeness and consistency require inclusion, although even a Variorum editor may think none worth the mention. For "What's in a name? That which we call a rose / By any other word would smell as sweet," one must be steeled to accept "cf. R178" (As sweet as a rose)-my most humiliating inclusion.

But a line, however shadowy, must be drawn somewhere. For Othello's "flinty and steel couch of war" (1.3.230), it seemed superfluous to cite the centuries old "hard as flint" and "hard as steel," although each phrase, when used in full, gets cited. Analogously, the even older and commoner "sweet as honey" and "honey-sweet" are dutifully acknowledged time after time after time. And here comes a surprise, I suspect. I, for one, would have expected "sweet as sugar" to be almost as common. But there is nothing in Tilley or OW, only five examples in Whiting, and I have myself recorded nothing between Tottel and Shakespeare. Accordingly, the index cites $\mathrm{S} 957.1$ for mere allusions to sugar's sweetness in The Merchant of Venice, and Richard II, and, of course (along with H544 and M930. I [Wh M544]), for Loz'e's Labor's Lost 5.2.230 f.:

Ber. White-handed mistress, one sweet word with thee.

Prin. Honey, and milk, and sugar: there is three.

31. I added C853 (He will say the crow is white) while in the process of writing this paragraph. Surely the commonness of making the crow white has something to do with making the white a crow. 
Slightly more than one-sixth of the citations in Tilley's "Shakespeare Index" are excluded from mine, ${ }^{32}$ but never merely because they seem too minor to be worth retaining. ${ }^{33}$ For example, since Tilley cites I66 (Ingratitude comprehends [is the worst of] all faults [vices]) for Viola's protestation against the charge of ingratitude (Tuelfth Night 3.4.354-357), this index retains that citation (the proverb is undeniably relevant to some degree, although neither used nor alluded to), but it does not make the same citation for several other anti-ingratitude passages (three of which encouraged my adding a questionable entry: I66.1 [Ingratitude is monstrous (a monster)]).

I have mentioned the use of a question mark, both in Appendix A for entries I think dubiously legitimate and in the index for citations whose relevance seems to me extremely marginal. Although no distinction can be apparent on the printed page, any user can readily distinguish between the question mark employed for near rejections and that used for some of the most interesting entries and citations in the volume-including those for several of the Falstaff passages discussed above, under "Precautions."

Neither the index nor Appendix A employs a question mark if the validity and relevance of an entry, no matter how trivial, seem certain to me. In many cases, especially in the late plays (some of which are predominantly allusive in their use of proverbs), there is little or no verbal resemblance between the passage in question and any examples of the proverb cited. But frequently there is no reason to doubt the allusion. Take "our stomachs / Will make what's homely savory" (C.ymbeline 3.6.32 f.). Although Tilley does not cite it, this seems to me an unmistakable allusion to H819 (Hunger is the best sauce). Or Macbeth's "Whole as the marble, founded as the rock, / As broad and general as the casing air" (3.4.21 f.). Again Tilley ignores, but this seems to me a good example of Shakespeare's increasing tendency to retain the noun and the sense of a proverbial simile while varying the adjective. Hence the index cites without question M638.1 (As hard as marble), R151 (As fixed [firm] as a rock), and even the less indisputable A88 (As free as the air). I can conclude with an example in both Tilley's index and mine, one that allows me to make a final plea against misuse of our indexes. In Henry VIII I.1.52 f., Buckingham says of Wolsey: "no man's pie is freed / From his ambitious finger." Obviously, he alludes to F228 (To have a finger in the pie). But merely to call his statement "proverbial," as Arden does, is a distortion of fact.

32. See "Precautions" and p. 3 f.

33. Where some particular word or words are essential to the entry, this index normally excludes Tilley citations lacking that essential. See p. xxi on "Fair face, foul hear" (F3), for example. Four of Tilley's citations for this proverb lack all four words; two others have but one. This index excludes all six. 